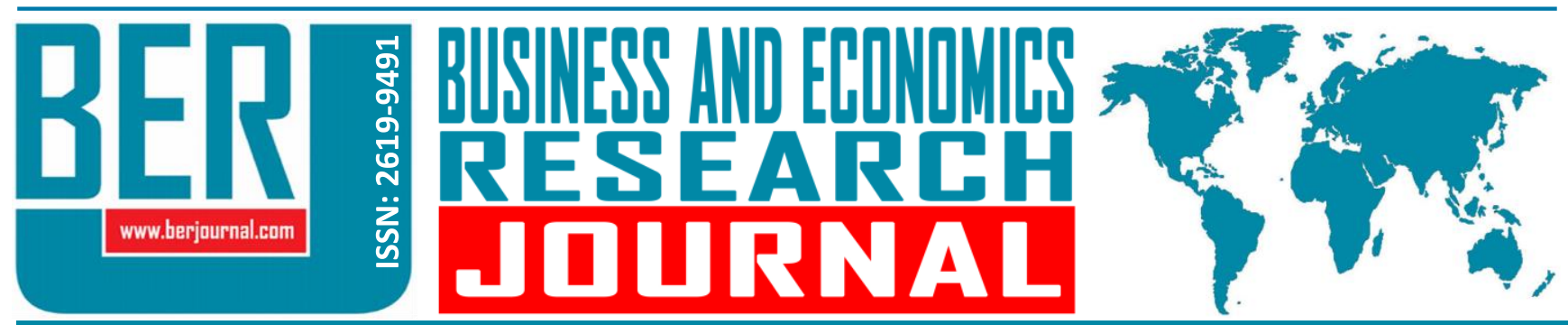

Business and Economics Research Journal Vol. 9, No. 3, 2018, pp. 619-630 doi: 10.20409/berj.2018.127

\section{Anonim Şirket Yönetim Kurulu Üyelerine Yapılan Ödemelerin Vergilendirilmesi}

\section{Ugur Yigit ${ }^{\mathrm{a}}$}

Öz: Anonim şirketler tarafından yönetim kurulu başkan ve üyelerine bu sıfatları nedeniyle değişik adlarla ödeme yapılabilir. Bir şirketin yönetim kurulu üyesi olan kişi aynı zamanda bu şirketin ortağı da olabilir. Şirket ortağı olması nedeniyle kendisine kar payı ödenebilir. Şirket yönetim kurulu üyesi ve şirket ortağı olan kişinin ayrıca şirkette hizmet sözleşmesine dayalı olarak genel müdür, genel müdür yardımcısı gibi bir sıfatla çalışması ve bu hizmeti karşılığında kendisine ücret ödenmesi de mümkündür. Bu durumda ilgili kişiye üç ayrı sıfatı (yönetim kurulu üyesi/şirket ortağı/şirket çalışanı) nedeniyle ödeme yapılabilir. Bu çalışmanın konusunu bir gerçek kişi yönetim kurulu başkan ve üyesine bu sıfatının yanı sıra aynı zamanda şirket ortağı ve şirket çalışanı olması durumunda yapılacak ödemeler ve bunların vergilendirilmesi teşkil etmektedir.

\section{Taxation of Payments to The Member of the Board of Directors of Joint-Stock Company}

Abstract: Chairman and the members of the board of directors can be made payments in different names by the joint-stock companies. A member of the board of directors of a company may be a shareholder of this company at the same time. Because of being a shareholder of the company, the member of the board of directors can be paid dividend. It is possible that a member of the board of directors of a company who is at the same time a shareholder of the company, may also be employed as general manager or assistant general manager based on a contract of employment and in return of this employment, wage can be payed. In this case, payment can be made to the relevant person based on the three titles (member of the board of directors/shareholder of the company/employee of the company). Both the payments made to a natural person chairman of the board of directors and a member, being a shareholder and an employee of the company at the same time and taxation of these payments constitute the subject of this study.
Anahtar Sözcükler: Yönetim Kurulu Üyesi, Şirket Ortağı, İşçi, Ücret, Kâr Payı

JEL: H27, H29, K34

Geliş : 20 Mart 2018

Düzeltme : 21 Mayıs 2018

Kabul : 28 Mayıs 2018

Tür : Derleme

Keywords: Member of the Board of Directors, Shareholder of a Company, Employee, Wage, Dividend

JEL: H27, H29, K34

Received : 20 March 2018

Revised : 21 May 2018

Accepted : 28 May 2018

Type : Review 


\section{Giriş}

6102 sayılı Türk Ticaret Kanunu'nun (TTK) 365’nci maddesinde de belirtildiği üzere anonim şirketler, yönetim kurulları tarafından temsil edilir ve yönetilir. Şirket esas sözleşmesinin verdiği yetkiye dayanarak yönetim hakkı, üyeler arasında taksim edilmemişse, her üye veya grup, kendi görevli olduğu kısımdan sorumlu olur (Öztürk, 2016g: 248). Şirketin mükellef veya vergi sorumlusu olmaları halinde bunlara düşen ödevler kanuni temsilcileri tarafından yerine getirilmektedir (Diliçıkık, 2015: 36; Uysal vd., 2009: 82; Bilici, 2014: 43). Şirketin yönetimi ve temsili ile yetkilendirilen kişilerin kamu hukuku vergi ve diğer kamu alacaklarının güvence altına alınması amacıyla özel hukuktan farklı olarak tüzel kişilik yanında kanuni temsilciyi de sorumlu tutmaktadır (Ayyıldırım vd., 2015: 77-78). Anonim şirketlerde, şirket mal varlığından tahsil edilemeyen kamu alacaklarından sorumluluk kapsamında kanuni temsilci yönetim kuruludur (Akdağ Güney, 2010: 11-12; Akdağ Güney, 2012: 167; Çamoğlu, 2010: 11-12; Öztürk, 2016c: 312).

Yönetim Kurulu başkan ve üyelerinin yaptıkları bu hizmetlerinin karşıı̆ı̆ olarak bir takım mali hakları vardır. TTK'nın "Yönetim kurulu üyelerinin mali hakları" başıklı 394'ncü maddenin 1'nci fıkrasında, yönetim kurulu başkan ve üyelerine bu sıfatları nedeniyle yapılan ödemeler; (Altaş, 2017: 316) huzur hakkı, ücret, ikramiye, prim ve kâr payı şeklinde beş kalem olarak sayılmıştır. Gelir Vergisi Kanunu ve bu Kanuna dayanılarak yayımlanan ikincil mevzuat uyarınca, şirket tarafından yönetim kurulu başkan ve üyelerine yapılabilecek olan bu beş tür ödemeden kâr payları menkul sermaye iradı diğerleri ise ücret kategorisi kapsamında vergilendirmeye konu teşkil eder (Öztürk, 2016a: 2026).

Şirket yönetim kurulu üyesinin aynı zamanda şirket ortağı olması durumunda şirket karından kâr payı alması da mümkündür. Yönetim kurulu üyesinin ortak sıfatıyla elde ettiği bu kâr payı menkul sermaye iradı olarak vergilendirilir.

Şirket yönetim kurulu üyesi ve şirket ortağı olan kişinin ayrıca şirkette hizmet sözleşmesine dayalı olarak genel müdür, genel müdür yardımcısı gibi bir sıfatla çalışması ve bu hizmeti karşılığında kendisine ücret ödenmesi de mümkündür. İşte bu durumda, hem yönetim kurulu üyesi hem de şirket ortağı olan kişinin bu iki sıfatına ilave olarak bir de iş akdi kapsamında iş̧̧i-işveren ilişkisine dayalı olarak anonim şirketten ücret alması söz konusu olabilecektir. 6102 sayılı Türk Ticaret Kanunu'nun 359'uncu maddesi ile tüzel kişilerin de anonim şirketlerin yönetim kurulu üyesi olmaları mümkün kılınmıştır (Ayrıntılı bilgi için bkz. Şener, 2015: 353357; Develi, 2016). Bu itibarla anonim şirket yönetim kurulu üyesi bir tüzel kişi de olabilecektir. Tüzel kişinin şirket yönetim kurulu üyesi ve aynı zamanda şirket ortağı olması mümkün olmakla birlikte şirket çalışanı yani "işçi" olması mümkün değildir. Nitekim 4857 sayılı İş Kanunu'nun 2'nci maddesinin 1'inci fıkrası uyarınca işçi; bir iş sözleşmesine dayanarak çalışan "gerçek" kişi olarak tanımlanmıştır. Bu tanımdan da anlaşılacağı üzere ancak gerçek kişiler iş̧̧i sıfatı ile iş sözleşmesine taraf olabileceklerdir. Bu itibarla çalışmamıza konu yönetim kurulu üyesinin aynı zamanda hem şirket ortağı hem de şirket çalışanı yani işçisi olabilmesi için gerçek kişi olması zorunludur.

Bu çalışma ile yönetim kurulu başkan ve üyesi olarak çalışan bir kişinin bu sıfatına ilave olarak şirket ortağı ve şirket çalışanı da olması durumunda kendisine yapılan ödemelerin niteliği ve vergilendirilmesi konusu incelenmiştir. Çalışmanın konusu yönetim kurulu üyesinin üç farklı pozisyonda şirketten aldığı ödemelere olduğundan burada yapılan inceleme yönetim kurulunun gerçek kişi üyeleri yönünden olacaktır. Diğer bir ifade ile anonim şirketin gerçek kişi yönetim kurulu üyelerine yapılan ödemelerin vergilendirilmesi ele alınacaktır.

\section{Yönetim Kurulu Üyeliği Sıfatıyla Yapılan Ödemeler}

Yönetim Kurulu, Anonim Şirketin iradesini oluşturmak, açıklamak ve uygulamak bakımlarından faaliyetlerinin ve tasarruflarının tümünü kapsar ve bunların sınılarını gösterir (Tekinalp, 2015: 237; Odman Boztosun, 2013: 73). Anonim şirkette yönetim kurulu üyeliği, ortaklık tarafından sağlanan mali haklar karşıı̆ı̆ında yapılan bir faaliyettir (Şener, 2015: 406). Diğer şirket ortaklarına kıyasla yönetim kurulu üyelerinin harcadıkları emek ve mesailerin şirket için önemi dikkate alındığında maddi kazanç sağlamaları da son derece doğaldır (Eriş, 2013: 2404-2405; Karahan, 2013: 425). TTK'nın 394'üncü maddesi; "Yönetim kurulu üyelerine, tutarı esas sözleşmeyle veya genel kurul kararıyla belirlenmiş olmak şartıyla huzur hakkı, ücret, ikramiye, prim 
ve yıllık kârdan pay ödenebilir." hükmünü amirdir. Bu hüküm mucibince şirketler, yönetim kurulu başkan ve üyelerine, belirtilen bu beş kalem ödemeden bir veya birkaçının yapılmasına karar verebilirler (Bahtiyar, 2015: 236-237; Bilgili vd., 2013: 390-392). Bu durum anılan madde gerekçesinde anılan malî hakların birkaçının bir arada yerine getirilmesine bir engel yoktur şeklinde ifade edilmiştir.

Anonim şirketler tarafından yönetim kurulu başkan ve üyelerine bu sıfatları yani yönetim kurulu başkanı ya da üyesi olmaları hasebiyle yapılan "huzur hakkı", "ücret", "ikramiye","prim" ve "kâr payı" şeklinde beş kalem altında sayılan ödemeler vergi kanunları açısından ya "ücret" ya da "kâr payı" niteliğini haizdir.

\subsection{Huzur Hakkı, Ücret, İkramiye, Prim Ödemeleri}

Anonim şirkette yönetim kurulu üyelerinin mali haklarından birisi huzur hakkıdır. Huzur hakkı, yönetim kurulu üyelerine yönetim kurulu toplantılarına katılmaları karşılığında her toplantı başına ödenen nakit (Tekinalp, 2015: 277) ücrettir (Şener, 2015: 409-410; Poroy vd., 2003: 319; Kayar, 2017: 459).

Ücret, yönetim kurulu toplantı sayısıyla ilgisi olmayan, (Tekinalp, 2015: 277) yönetim kurulu üyelerine yerine getirdikleri görevler dolayısıyla belirli bir dönem için ödenen paradır (Karay, 2017: 459). Genel olarak ücret ise sırf emek veya işten elde edilen gelire verilen addır (Erginay, 1987: 62).

İkramiye, yönetim kurulu üyelerine, gösterdikleri başarılı faaliyetler nedeniyle yapılan ödemedir. İkramiye ası ücrete ek olarak yapmış olduğu katkılardan dolayı hoşnutluğu belirtmek amacıyla bazı vesilelerle (noel, yılbaşı, iş yılının sona ermesi gibi) verilen özel bir ücrettir (Çelik, 2004: 136; Mollamahmutoğlu vd., 2014: 44; Çenberci, 1986: 672; Günay, 2006: 37; Gümüş, 2013: 438; Keser, 2010: 231). İkramiye ödenebilmesi için genel kurulun takdiri veya ortaklık ana sözleşmesinde hüküm bulunması esastır (Şener, 2015: 407; Poroy vd., 2003: 319; Karay, 2017: 460).

Prim, yönetim kurulu üyelerine anonim şirketi daha iyi profesyonel bir şekilde yönetmelerini teşvik etmek amacıyla yapılan ödemedir (Karay, 2017: 461). Ödenebilmesi için genel kurulun takdiri veya ortaklık ana sözleşmesinde hüküm bulunması esastır (Çelik, 2017: 209). Primin temel amacı, üstün başarıyı (Çelik, 2004: 135) ödüllendirmek için ödenen ek ücrettir (Süzek, 2017: 361; Mollamahmutoğlu vd., 2014: 629; Günay, 2006: 38; Evcil vd., 2010: 19; Uygur, 2012: 1983). Prim ikramiyeden farklıdır. Ikramiye genellikle bazı özel nedenlerle; prim ise yapılan işteki başarı ve elde edilen sonuca bağılıı (Sümer, 2017: 77). [Sosyal güvenlik primlerinin hukuki niteliğine ilişkin farklı görüşler ileri sürülmüştür. Bir görüşe göre, primler ücretin özel bir şeklidir (Öztürk, 2016f: 305).]

Anonim şirketler tarafından yönetim kurulu başkan ve üyelerine yapılan huzur hakkı, ücret, ikramiye, prim adı altında yapılan ödemeler yukarıda tanımlarından anlaşıldığı üzere her ne kadar ödenmesindeki amaç, miktar, süre ve içerik itibarıyla farklı olsalar da vergilendirme bakımından hepsi ücret adı altında ve ücrete dâhil olarak işlem görürler. Anılan maddede beşinci mali hak olarak yer alan "yıllık kârdan pay" ödemesi ise aşağıda açıklanacağı üzere ücret geliri olarak değil menkul sermaye iradı olarak vergilendirilir (Öztürk, 2016d: 63-64).

Nitekim, GVK'nın “Ücretin Tarifi” başlıklı 61'inci maddesinde; "Ücret, işverene tabi belirli bir işyerine bağlı olarak çalışanlara hizmet karşıı̆ı verilen para ve ayınlar ile sağlanan ve para ile temsil edilebilen menfaatlerdir. Ücretlerin ... huzur hakkı, prim, ikramiye, ... veya başka adlar altında ödenmiş olması .... onun mahiyetini değiştirmez." hükmüne yer verilmiştir. Bu itibarla, TTK'nın 394'üncü maddesinde, anonim şirketler tarafından yönetim kurulu üyelerine ödenecek mali haklar olarak sınırlı sayı ilkesine göre belirlenmiş bulunan beş mali haktan dördü olan "huzur hakkı", "ücret", "ikramiye" ve "prim" ödemeleri GVK'nın 61/3-4 maddesi kapsamında "ücret" niteliğinde olup tüm bu ödemeler ücretlerin vergilendirilmesine ilişkin esaslar kapsamında vergiye tabi tutulur (Kırca vd., 2013: 728). Ücrete ek olarak yapılan ve "fringebenefits" olarak isimlendirilen, servis, tatil, lojman, gibi ödemeler de ücretin bir unsurudur (Öz, 2006: 113). Yapılan ödemenin; ödenek, tazminat, kasa tazminatı, mali sorumluluk tazminatı, tahsisat, zam, avans, aidat, huzur hakkı, prim, ikramiye, gider karşıı̆ığı veya başka adlar altında ödenmiş olması veya bir ortaklık ilişkisi niteliğinde olmaması şartı ile kazancın belli bir yüzdesi şeklinde tespit edilmiş olması, ücretin niteliğini değiştirmez. Böylece kanun, terminoloji kargaşasının uygulamada tereddüt yaratmasını engellemek istemektedir. Ayrıca arada bir ortaklık 
ilişkisinin bulunmadığı durumlarda, ücretin kazancın belli bir yüzdesi olarak kararlaştırılmış bulunmasını da aynı esasa bağlamıştır (Öncel vd., 2014: 289). Ancak, ücretin kazancın belli bir yüzdesi olarak belirlenmiş olması ile yönetim kurulu üyelerine kârdan pay verilmesinin aynı anlama gelmediğini belirtmekte yarar vardır. Yönetim kurulu üyesine her ay için ya da her bir toplantı başına belli bir meblağ örneğin; 2.500-TL huzur hakkı ödenmesi GVK'nın 61/3-4 maddesi uyarınca tartışmasız olarak ücrettir. Aylık 2.500-TL sabit bir tutar yerine şirket kârının \%1'inin ücret olarak belirlenmiş olması da ortaklık münasebeti niteliğinde olmayıp, yönetim kurulu üyeliği görevi nedeniyle yapılan bir ödeme olduğundan ücret niteliğindedir. Buna karşılık şirket karından \%1 oranında yönetim kurulu üyesine yapılan kâr payı ödemesi ise ücret niteliğinde değildir (Öztürk, 2016d: 63).

GVK'nın 61'inci maddesi gereğince, bir ödemenin ücret olarak tavzih edilebilmesi için üç özelliği birlikte taşıması gerekir. Birincisi, hizmetin işverenle hizmet erbabı arasında bağııık ilişkisi içerisinde işverene tabi olarak verilmesi gerekir. İkincisi, istisnaları olsa da genel olarak hizmetin bir işyerine bağlı olarak yapılması, işveren tarafından gösterilecek belirli bir işyerinde sunulması zorunludur. Üçüncü olarak da, ödemenin hizmet karşılığı yapılmasıdır. Herhangi bir hizmet karşılığı olmayan ödemeler ücret kapsamına girmez (Kızılot vd., 2011: 238). Ücret gelirinin özelliği emek karşılığı elde edilmiş ya da emek ağırlıklı olarak yürütülen faaliyetlerden doğmuş olmasıdır. Üretime katılan emek bedensel ya da zihinsel olabilir. Bir hizmet akdi ile işverene bağımlı olarak çalışma karşılığı elde edilen gelir, kanuna göre ücret sayılmıştır. Kısaca nitelersek, ücret bağımlı emeğin gelirini oluşturur (Öncel vd., 2014: 243). Hizmetle ilişkisi olmayan, hiç bir emek sunumunun karşılığı olmayan ödemeler ücret sayılamaz. Eğer işveren ile işgören arasında bir iş akdi ya da toplu sözleşme varsa, bu kişiye yapılan bütün ödemelerin ücret olarak vergi kesintisine tabi olduğu varsayımı yapılır (Bulutoğlu, 2004: 47).

GVK'nın 61'inci maddesinin 3'ncü fıkrasında ilk iki fıkra kapsamı dışında kalan bir takım ödemelerin de bu Kanun'un uygulanmasında ücret sayılacağı hükme bağlanmıştır (Çolak, 2004: 43; Öz, 2006: 113). Bu ödemeler arasında, yönetim kurulları başkan ve üyelerine "bu sıfatları dolayısıyla" ödenen veya sağlanan para ayın ve menfaatler de sayılmıştır (Öztürk, 2016d: 60). Böylelikle gelir türü olarak niteliği tartışmaya açık bir kazançların ücret olup olmadıkları konusunda hem şüpheler giderilmiş olmakta hem de o kazanç unsuru vergilendirme tekniği, istisnalar vb. açısından, dâhil edildiği kategorinin statüsüne tabi olmaktadır (Öztürk, 2016e: 64). Milletvekillerinin aylıkları düşünüldüğünde bağımlı olarak çalışma ilişkisinin bu statüde geçerli bulunmaması nedeniyle ödemenin ücret olarak vergilendirilip vergilendirilemeyeceği uyuşmazlık konusu olabilir. Bilirkişi ücretleri için de aynı durum geçerlidir (Öncel vd., 2014: 289-290).

Benzer şekilde, GVK'nın 61'inci maddesinde yer alan "ücret" tanımının, yönetim kurulu üyelerine yapılan ödemelerini kapsayıp kapsamadığı hususu tartışmalıdır. TTK uyarınca yönetim kurulu üyesi ile şirket arasındaki ilişki iş akdi olmayıp (Korkut, 2007: 9-22), kural olarak (Farklı görüş için bkz. Kırca vd., 2013: 454) vekâlet (Karahan, 2013: 416; Pulaşlı, 2014: 972-974) ilişkisidir. Hal böyle olunca yönetim kurulu üyesinin "bağımlı" olarak çalıştığını söylemek güçtür. Bir başka ifade ile GVK'nın 61'inci maddesinin 1'inci fıkrasındaki ücret tanımı, yönetim kurulu başkan ve üyelerine yapılan ödemeleri bu tanıma dahil etme konusunda, bağımlı çalışma koşulu nedeniyle yetersiz kalmaktadır (Çelik vd., 2014: 103).

Bu sebeple, ücrete ilişkin genel tanımın, yönetim kurulu üyelerine yapılan ödemeleri ücret olarak kavrama noktasında bir zafiyet göstermesi intimaline karşı, tanım ile yetinilmemiş yönetim kurulu üyelerine bu sıfatları dolayısıyla ödenen veya sağlanan para, ayın ve menfaatlerin ücret sayılacağı hususu ayrıca hükme bağlanmıştır. Böylelikle bu ödemelerin ücretler kapsamında vergilendirilmesi sağlanmıştır (Öztürk, 2016d: 6162).

Yönetim kurulu üyelerine yapılan ödemelerin, GVK'nın 61'inci maddesinin 3'üncü fıkrasının (4) numaralı bendi uyarınca ücret sayılabilmesi için söz konusu ödemelerin "yönetim kurulu üyesi sıfatıyla" yapılmış olması önemlidir. Zira bu kişilere diğer sıfatları dışında, yönetim kurulu üyesi olmaları dolayısıyla yapılan ödemeler ücret kapsamına girmektedir.

Gerçek kişi yönetim kurulu üyelerine ödenen ücret GVK 94/1 uyarınca stopaj vergisine tabidir ve şirket bu bedeli gider olarak belirtebilir. Tüzel kişi yönetim kurulu üyelerine yapılacak ödemelerin ise GVK kapsamında ücret niteliği yoktur. Dolaysıyla tüzel kişi yönetim kurulu üyesi bakımından kurum kazancı olarak 
Kurumlar Vergisine tabidir (Develi, 2016: 131). Ödemeyi alan tüzel kişi bunu gelir olarak kaydedebilirken, ödemeyi yapan şirket bu ödemeyi gider olarak gösteremez, çünkü yapılan ödeme niteliği itibarıyla kâr payıdır ve kâr payı vergiden sonraki kazanç üzerinden yapılır (Yüce, 2014: 87).

Bu çalışma kapsamında, yönetim kurulu üyesi olarak çalışan kişi bu sıfatının dışında ayrıca şirket ile bir hizmet sözleşmesine dayalı olarak iş akdi kapsamında iş̧̧i-işveren ilişkisi kurmuş ve bu ilişki nedeniyle örneğin; genel müdür, genel müdür yardımcısı sıfatıyla da çalışıyor ve bu çalışma karşılığında ayrıca bir ücret alıyor ise bu ücret ödemesinin de ücret geliri olarak vergilendirilmesi gerektiği açıktır.

\subsection{Kâr payı Ödemeleri}

Kâr payı (kazanç payı) uygulamada yönetim kurulu üyelerine bir teşvik tedbiri olarak, ortaklık kazancından pay verildiği de sık görülmektedir (Poroy vd., 2003: 319; Karay, 2017: 460). Kârdan pay vermek, sabit ücret vermekten daha yararlı, hem yönetim kurulu üyelerini daha çok çalışmaya teşvik edici, hem de duruma göre çalışmayanı cezalandırıcı bir fonksiyona sahiptir (Şener, 2015: 407).

GVK'nın 75'inci maddesinin birinci fıkrasında menkul sermaye iradı, sahibinin ticari, zirai veya mesleki faaliyeti dışında nakdi sermaye veya para ile temsil edilen değerlerden müteşekkil sermaye dolayısıyla elde ettiği kâr payı, faiz, kira ve benzeri iratlar olarak tanımlanmıştır. Buna göre bir gelirin menkul sermaye iradı sayılabilmesi için; iradın, nakdi sermaye veya para ile temsil edilen değerlerden oluşan sermaye vasıtasıyla sağlanması, irat sahibinin ticari, zirai veya mesleki faaliyetleri dışında elde edilmiş olması ve yatırılan sermaye dolayısıyla temettü, faiz, kira veya benzeri bir irat elde edilmiş olması gerekir (Mutluer, 2014: 429-430; Türkmen, 2015: 185).

GVK'nın 75'inci maddesinin 2'nci fıkrasında kaynağı ne olursa olsun bu fıkrada yazılı iratların menkul sermaye iradı sayılacağı hükme bağlanmıştır. Bu hüküm uyarınca $75^{\prime}$ inci maddenin 1 'inci fıkrasında yapılan genel tanım kapsamında olmayan bazı iratlar tek tek sayılmak suretiyle menkul sermaye iradı kapsamına alınmış ve bu iratların menkul sermaye iradı olarak vergilendirilmesi (Ekici, 2011: 116; Altındağ, 2002: 72-73) amaçlanmıştır (Öztürk, 2016b: 108; Şener vd., 2012: 171). Yönetim kurulu üyelerine verilen kâr payları da sayılan bu unsurlar arasında, (3) numaralı bentte yer almaktadır. Böylece yönetim kurulu üyelerine verilen kâr payları da menkul sermaye iradı olarak nitelendirilmiştir (Öner, 2013: 329). GVK'nın 75/1 maddesinde yer alan menkul sermaye iradına ilişkin genel tanıma bakıldığında içeriği itibarıyla yönetim kurulu üyelerine bu sıfatları dolayısıyla ödenen kâr paylarını, sermaye dolayısıyla elde edilmediklerinden, menkul sermaye iradı olarak vergilendirmeye imkan vermez. Bu sebeple aynı maddenin 2 'nci fıkrasında ayrıca sayılmak suretiyle, yönetim kurulu üyelerine verilen kâr paylarının menkul sermaye iradı olarak nitelendirilmesi sağlanmıştır (Öztürk, 2016b: 108).

Yönetim kurulu üyelerine ödenen kâr paylarının, GVK'nın 75'inci maddesinde değiş̧iklik yapan 2361 sayılı Kanun gerekçesinde yer alan "Kurumların idare meclisi başkan ve üyelerine verilen kâr payları menkul sermaye iradı sayılmaktadır. Daha önce de açıklandığı üzere, ücretin tarifi ile ilgili 61 'inci maddenin 3 numaralı bendinden, bu tür ödemeler çıkarılmıştır. Böylece, kurumlarda idare meclisi başkan ve üyelerine verilen kâr paylarının ücret adı altında Kurumlar vergisi matrahı dışında bırakılması şeklindeki uygulamanın sakıncaları da önlenmiş olacaktır" açıklamasından da anlaşılacağı üzere menkul sermaye iradı olarak vergilendirilmesi kanun koyucunun bilinçli bir tercihidir (Öztürk, 2016b: 108).

\section{Anonim Şirket Ortağı Sıfatıyla Yapılan Kâr Payı Ödemeleri}

Kâr payı ve temettü kavramları, Türk Hukukunda ilk kez Sermaye Piyasası Kurulu'nun 13.11.2001 tarihinde Resmi Gazetede yayınlanan "Sermaye Piyasası Kanununa Tabi Olan Halka Açık Anonim Ortaklıkların Temettü ve Temettü Avansı Dağıtımında Uyacakları Esaslar Hakkında Tebliğ" başılılı Seri: IV, No:27 sayılı tebliği ile tanımlanmıştır. Buna göre, kâr payı ortaklara ve kâra katılan diğer kimselere dağıtılacak kârdan, bunların her birine düşen pay; temettü ise ortaklara dağıtılacak kâr payını ifade eder.

Diğer bir tarife göre kâr payı, şirket ortaklarına ve kâra katılan yönetim kurulu üyelerine, iş̧̧ilere, intifa senedi sahiplerine vb. diğer kimselere dağıtılacak kârdan, bunların her birine düşen payı; temettü ise sadece kârdan şirket ortaklarına dağıtılan payı ifade etmektedir (Akbulak, 2002: 120). Yine öğretide (farklı 
tanımlamalar için bkz. Karayalçın, 1990: 127; Ansay, 1982: 232; Sengir, 1973: 77) kâr payı; anonim şirketlerde dağıtılmasına genel kurul tarafından karar verilen kârın, münferit pay (Sevi, 2004: 21) sahibine (Yıldız, 2004: 68-69) şirket tarafından ödenmesi gerekli ve miktarı belli edilmiş kısmıdır (Ünal, 1998: 43).

Kâr payı hakkı ise bu anlamda kanun ve esas sözleşme hükümlerine göre dağıtılmaya tahsis edilen yıllık kâra veya dağıtılmaya tahsis olunan yedek akçelere, pay sahibinin katılma hakkıdır. Bu anlamda kâr payı hakkı nispî müktesep haktır (Ünal, 2001: 18).

GVK'nın75'inci maddenin 2'nci fıkrasının (1) numaralı bendi uyarınca her nevi hisse senetlerinin kâr payları -kurucu hisse senetleri ve diğer intifa hisse senetlerine verilen kâr payları ve pay sahiplerine hazırlık dönemi için faiz olarak veya başka adlarla yapılan her türlü ödemeler ile Sermaye Piyasası Kanununa göre kurulan yatırım fonları katılma belgelerine ödenen kâr payları ile konut finansmanı fonlarını temsilen ihraç edilen ipoteğe dayalı menkul kıymetlere ve varlık finansmanı fonlarını temsilen ihraç edilen varlığa dayalı menkul kıymetlere ödenen faiz, kâr payı veya benzeri gelirler dahil- menkul sermaye iradı niteliğindedir.

Şirket ortaklarına ödenen kâr payları da yukarıda açıklandığı üzere şirket yönetim kurulu üyelerine yönetim kurulu üyeliği görevi nedeniyle ödenen kâr payları gibi menkul sermaye iradı mahiyetini taşımaktadır. Daha açık bir ifade ile GVK'nın75'inci maddesinin 1'inci fıkrası ile 2'inci fıkrasının (1) ve (3) numaralı bentlerinin birlikte değerlendirilmesinden anonim şirket ortağı olan kişiye ortak sıfatı ile ödenen kâr paylarının ve anonim şirket yönetim kurulu üyesi olan kişiye yönetim kurulu üyesi olması nedeniyle ödenen kâr paylarının her ikisinin de menkul sermaye iradı olarak vergilendirilmesi gerektiği anlaşılmaktadır.

Anonim şirket yönetim kurulu üyesi aynı zamanda bu şirketin hisselerine sahip yani şirket ortağı ise şirket karından ortaklık payı oranında aldığı kâr payı (temettü) bu kişinin geliri olup bu gelir menkul sermaye iradı olarak vergilendirilir.

\section{Hizmet Akdine Dayalı Olarak Yapılan Ücret Ödemeleri}

Hizmet Sözleşmesi 6089 sayılı Borçlar Kanunu’nun 393'üncü maddesinde işçinin işverene bağımlı olarak belirli veya belirli olmayan süreyle işgörmeyi ve işverenin de ona zamana veya yapılan işe göre ücret ödemeyi üstlendiği sözleşmedir şeklinde tanımlanmıştır. Bu tanımdan hareketle hizmet sözleşmesinin unsurları; -hizmet görenin bir süre işverene bağımlılık ilişkisi içinde bir hizmet görmesi veya görmeyi vaad etmesi, -hizmet görülmesinin veya hizmet ediminin vaadinde bulunulmasının bir ücret karşılığında olması, tarafların anlaşması veya bir karşılık ödenmesine yol açacak bir hizmet ilişkisinin varlığı olarak sayılmıştır (Yavuz, 2004: 242-243).

Bir anonim şirketin yönetim kurulu üyesi olan kişi aynı zamanda bu şirketin ortağı da olabilir. Şirket yönetim kurulu üyesi ve şirket ortağı olan bu kişi ayrıca aynı şirkette hizmet sözleşmesine dayalı olarak genel müdür, genel müdür yardımcısı gibi bir sıfatla çalışması ve bu hizmeti karşılığında kendisine ücret ödenmesi de mümkündür. Müdürler, yönetim kurulu üyeleri, paysahipleri hatta üçüncü kişiler arasından da seçilebilirler (Poroy vd., 2003: 364) ve kendilerine sağlanacak mali haklarda bu sıfatlarına göre değişir (Özer, 2013: 67). Örneğin anonim şirket statüsündeki bankaların genel müdürü (Tekinalp, 2009: 177; Paslı, 2005: 345). Ücret hakkı müdürlerle anonim ortaklık arasındaki ilişkisinin hizmet sözleşmesi karakterli oluşunun doğal bir sonucudur. Ücret Hakkı, müdürün iş görme borucunun karşılığını oluşturmaktadır (Karaca, 2010: 115).

GVK'nın "Ücretin Tarifi" başlıklı 61'inci maddesinde; "Ücret, işverene tabi belirli bir işyerine bağı olarak çalışanlara hizmet karşılığı verilen para ve ayınlar ile sağlanan ve para ile temsil edilebilen menfaatler" olarak tanımlanmıştır. Anonim şirket yönetim kurulu üyesinin aynı zamanda şirkette genel müdür, genel müdür yardımcısı gibi bir sıfatla hizmet görmesi durumunda bu hizmetin karşılığı olarak kendisine yapılan ödemeler GVK'nın 61'nci maddesindeki tanım kapsamında ücret niteliğindedir. Mezkur madde uyarınca bu ücretin ödenek, tazminat, kasa tazminatı (Mali sorumluluk tazminatı), tahsisat, zam, avans, aidat, huzur hakkı, prim, ikramiye, gider karşılığı veya başka adlar altında ödenmiş olması veya bir ortaklık münasebeti niteliğinde olmamak şartı ile kazancın belli bir yüzdesi şeklinde tayin edilmiş bulunması mahiyetini değiştirmeyecektir (Şener vd., 2012: 175). 
Öte yandan, yukarıda değinildiği üzere, şirkete hizmet akdi ile bağlı olarak çalışanlara ücretlerinin kâra göre ödenmesi son zamanlarda çok uygulanan bir ücret rejimi olup ödenecek ücretin işletme kârına göre hesaplanması, ücretin miktarını saptama şeklinden başka bir şey olmadığından elde edilen kâr üzerinden hesaplanan ücretlerin niteliği de diğer "ücretler" ile aynıdır (Erimez, 1985: 209).

Anonim şirket yönetim kurulu üyesinin yönetim kurulu üyesi görevinin dışında hizmet karşılığı olarak şirketten aldığı paraların ücret olarak nitelendirilmede kanunen aranan ve yukarıda değinilen üç özelliğe de aynı anda sahip olduğunu söylemek mümkündür. Birincisi, ödemeye konu hizmet bir işverene tabi olarak verilmektedir. Burada işveren anonim şirkettir. İşverenle hizmet erbabı arasında bağlıık ilişkisi vardır. Hizmet erbabının yaptığı çalışma kendi adına değil; işverenin adına ve işverenin çizdiği sınırlar içindedir. İkincisi, hizmet bir işyerine bağlı olarak yapılmaktadır. Hizmet erbabı emeğini, belirli bir işyerinde sunmaktadır. Üçüncüsü de ödeme hizmet karşılığı yapılmaktadır.

Anonim şirket yönetim kurulu üyesine, tıpkı yönetim kurulu üyesi sıfatıyla yapılan; huzur hakkı, ücret, ikramiye ve prim ödemeleri gibi yönetim kurulu üyesi kişiye şirketle imzaladığı iş sözleşmesine dayanılarak hizmet karşılığı olarak yapılan ödemeler de GVK'nın 61'inci maddesinin 1'inci fıkrası kapsamında "ücret" niteliğindedir.

\section{Yönetim Kurulu Başkan Ve Üyelerine Yapılan Ödemelerin Vergilendirilmesi}

Bu çalışmanın konusunu oluşturan kişi, hem yönetim kurulu üyesi hem şirket ortağı hem de hizmet akdine bağlı olarak şirket çalışanı yani iş̧̧i vasfı taşıyan kişidir. Bu kişiye bu üç vasfı nedeniyle yapılan tüm ödemeler vergilendirme açısından "ücret" ya da "kâr payı" niteliğindedir. Bu itibarla yönetim kurulu başkan ve üyelerine yapılan ödemelerin vergilendirilmesi konusu bu iki başlık altında ele alınacaktır. Nitekim GVK'nın2'nci maddesinde sayılan, gelire giren kazanç ve iratlar dikkate alındığında şirket yönetim kurulu üyesi, şirket ortağı ve aynı zamanda şirket çalışanı olan ve çalışmamıza konu teşkil eden kişilere yapılan tüm ödemelerin "ücretler" ya da "menkul sermaye iratları" kapsamında vergilendirilmesi gerekir. Anonim şirketler tarafından yönetim kurulu başkan ve üyelerine yapılan ödemelerin bu iki gelir kategorisi dışında bir başka gelir kategorisine dahil edilmesi mahiyetleri itibarıyla mümkün bulunmamaktadır. Bu ödemelerin örneğin ticari kazanç, zirai kazanç ya da gayrimenkul sermaye iradı olarak nitelendirilmesi mümkün değildir.

\section{1. Ücret Ödemelerinin Vergilendirilmesi}

Yukarıda belirtilen ve bu çalışmanın konusunu oluşturan hem yönetim kurulu üyesi hem şirket ortağı hem de hizmet akdine bağlı olarak işçi vasfı taşıyan kişinin yönetim kurulu üyesi sıfatıyla elde etmiş olduğu huzur hakkı, ücret, ikramiye, prim ödemeleri ile şirket ile kurmuş olduğu genel müdür, genel müdür yardımcısı gibi hizmet ilişkisinden kaynaklanan ücret ödemelerinin GVK uyarınca "ücretler" kapsamında vergilendirilmesi gerekecektir. Daha açık bir ifade ile söz konusu ödemeler vergi kanunları açısından ücret ödemesi/ücret geliri niteliğindedir.

Ücret gelirlerinin vergilendirilmesinde GVK, "gerçek usul" (63.md.) ve "diğer ücretler" (64.md.) olmak üzere iki ayrı usul kabul etmiştir. Ancak vergilendirilmede ilke olarak gerçek usul geçerlidir. Hizmet erbabına ödenen ücretler ile Kanun gereğince ücret sayılan ödemelerden tevkifat yapılır (GVK, md.94). Bu nedenle yönetim kurulu üyelerine yapılan; huzur hakkı, ücret, ikramiye ve prim ödemeleri üzerinden şirketlerce gelir vergisi tevkifatı yapılması gerekir. İ̧ verenler, hizmet erbabına ödedikleri ücretlerden 94 üncü madde gereğince yaptıkları vergi tevfikatını Vergi Usul Kanununda yazılı ücret bordrosunda veya bordro yerine geçen diğer kayıtlarda göstermeye mecburdurlar. (GVK, md.97).

Tevkifata tabi olmayan ücretler GVK'nın 95'inci maddesinde belirtilmiş olup bu ücretler yıllık beyanname ile bildirilir. Bununla birlikte yönetim kurulu başkan ve üyelerine yapılan ücret ödemeleri bu madde kapsamına girmediğinden yıllık beyanname usulüne tabi değildir, bu nedenle tevkifata tabi tutulur.

Tek işverenden alınmış ve tevkif suretiyle vergilendirilmiş ücretler için yıllık beyanname verilmez, diğer gelirler için beyanname verilmesi halinde bu gelirler beyannameye dahil edilmez. Birden fazla işverenden ücret almakla beraber, birden sonraki işverenden aldıkları ücretlerin toplamı, GVK'nın 103'üncü maddesinde yazılı tarifenin ikinci gelir diliminde yer alan tutarı aşmayan mükelleflerin, tamamı tevkif suretiyle 
vergilendirilmiş ücretleri için de beyanname verilmez (GVK, md.86). Yönetim kurulu başkan ve üyeleri ister yönetim kurulu üyesi sıfatıyla isterse de şirketle aralarında kurulmuş olan iş sözleşmesine dayanarak aldıkları ücret tek işverenden alındığından bu ücretler üzerinden gerekli tevkifat yapılmış ise beyanname verilmesine gerek yoktur. Ancak birden fazla işverenden ücret alınması durumunda, gelir vergisi tarifesindeki artan oranlılı̆ın vergi tutarına yansımasını teminen yıllık beyanname verilmesi gerekir (Öztürk, 2016a: 2043).

Birden fazla işverenden elde edilen ücretlerin toplamı 103 üncü maddede yazılı tarifenin ikinci gelir diliminde yer alan tutarı aşması durumunda, ücretlerin tamamı (ilk işverenden alınan ücrette dâhil olmak üzere) yıllık beyannameye dâhil edilecektir. Daha açık bir ifade ile yönetim kurulu üyesi ve aynı zamanda da hizmet sözleşmesi ile şirket çalışanı konumunda bulunan kişi, söz konusu şirket dışında başka bir işverenden de ücret alıyorsa, birinci işverenden alınan ücretin hangisi olacağını serbestçe belirleyebilecek ve gelirlerini beyan edecektir. Gelirin toplanmasına ilişkin GVK'nın 86'ncı maddesi hükmüne göre; birden fazla işverenden ücret alıp da birden sonraki işverenden aldıkları ücretlerin toplamı gelir vergisi tarifesinin ikinci diliminde yazılı tutarı aşan çalışmamıza konu teşkil eden yönetim kurulu üyelerinin yıllık beyanname vermeleri gerekir (Öztürk, 2016d: 69).

Ücret gelirleri, stopaj yöntemine tabi diğer gelir unsurlarından farklı olarak, safi tutar üzerinden vergilendirilir (GVK, md.96/2). Vergilendirmede ücretin yıllık toplamı esas alındığından artan oranlı tarifenin uygulanması söz konusudur (GVK, md.104). Anonim şirket tarafından, yönetim kurulu başkan ve üyelerine yapılan ücret ödemeleri dolayısıyla kesilen vergi, kesintinin yapıldığı ayı izleyen ayın 23 'üncü günü akşamına kadar ilgili vergi dairesine muhtasar beyanname ile beyan edilir ve beyanname verilen ayın 26 'ncı günü akşamına kadar ödenir. Şirketin çalıştırdığı hizmet erbabı sayısı 10 ve daha az olanlar, 94 üncü maddeye göre yapacakları tevkifatla ilgili muhtasar beyannamelerini, bağlı bulundukları vergi dairesine önceden bildirmek şartıyla her ay yerine Ocak, Nisan, Temmuz ve Ekim aylarının yirmi üçüncü günü akşamına kadar verebilirler (GVK, md.98).

\subsection{Kâr paylarının Vergilendirilmesi}

Şirketin hem yönetim kurulu üyesi, hem ortağı hem de çalışanı olan kişinin yönetim kurulu üyesi sıfatıyla ve ortak sıfatıyla şirketten aldığı kâr payları gelir vergisi kanunu uyarınca menkul sermaye iradı olarak vergilendirilir. Bu vergilendirme hem kâr payını elde eden kişi hem de kâr payı ödemesini yapan şirket nezdinde ayrı ayrı yapılır.

\subsubsection{Kâr Payı Ödemelerinin Elde Eden Yönetim Kurulu Üyesi Bünyesinde Vergilendirilmesi}

Anonim şirketin hem yönetim kurulu üyesi, hem de ortağı yani hisse senedi sahibi olan kişi bu iki sıfatı nedeniyle elde ettiği kâr paylarından dolayı vergilendirilir.

GVK'nın 22/2 maddesi uyarınca Tam mükellef kurumlardan elde edilen, 75 inci maddenin ikinci fıkrasının (1), (2) ve (3) numaralı bentlerinde yazııı kâr paylarının yarısı gelir vergisinden müstesnadır (Ateşağaoğlu, 2012: 310; Tuncer, 2003: 4). İstisna edilen tutar üzerinden 94 üncü madde uyarınca tevkifat yapılır ve tevkif edilen verginin tamamı, kâr payının yıllık beyanname ile beyan edilmesi durumunda yıllık beyanname üzerinden hesaplanan vergiden mahsup edilir. İstisna dışında kalan tutar, GVK'nın 86'ncı maddesine göre Kanun'un 103'üncü maddesinde yazılı tarifenin ikinci gelir diliminde yer alan tutarı aşıyorsa yıllık beyanname ile beyan edilecektir (Aygün, 2012: 72). Kâr payının beyanı halinde kurum bünyesinde yapılan tevkifatın tamamı yıllık beyanname üzerinden hesaplanan gelir vergisinden mahsup edilecektir (Öztürk, 2012: 97). Mahsup sırasında tevkifat yoluyla kesilen verginin beyanname ile hesaplanan vergiden fazla olması halinde kalan tutar iade edilecek, aksi takdirde hesaplanan vergi iki eşit taksitte ödenecektir (Öztürk, 2016d: 71-72). Beyanname mart ayında verilir (GVK, md.92) ve tahakkuk eden vergi mart ve temmuz olmak üzere iki eşit taksitte ödenir (GVK, md.117).

Tam mükellef kurumlardan elde edilen ve kurumların idare meclisi başkan ve üyelerine ya da ortaklık münasebeti nedeniyle aynı zamanda şirket ortağı da olan yönetim kurulu üyesine verilen kâr paylarının yarısı gelir vergisinden istisna olup, kalan tutar vergiye tabi gelir olarak dikkate alınacaktır. Beyana tabi başka gelirlerin bulunmaması halinde, gelir 2018 yılı için 34.000-TL'yi aşıyor ise beyan edilecektir. Beyan edilen tutar 
üzerinden hesaplanan gelir vergisinden, kurum bünyesinde kârın dağıtımı aşamasında yapılan \%15 oranındaki vergi kesintisinin tamamı (istisnaya isabet eden kısım dahil) mahsup edilecek olup, mahsup sonrası kalan tutar genel hükümler çerçevesinde red ve iade edilecektir (Öztürk, 2016b: 109).

Tüm bu açıklamalar kâr payını elde eden anonim şirket yönetim kurulu üyesi ve aynı zamanda anonim şirket ortağı olan "gerçek kişiler" için geçerlidir. Nitekim, çalışmamıza konu kişiler de gerçek kişidir.

\subsubsection{Kâr Payı Ödemelerinin Ödemeyi Yapan Anonim Şirket Bünyesinde Vergilendirilmesi}

GVK'nın 94/6-b maddesinde; tam mükellef kurumlar tarafından tam mükellef gerçek kişilere, gelir ve kurumlar vergisi mükellefi olmayanlara ve bu vergiden muaf olanlara, dar mükellef gerçek kişilere, dar mükellef kurumlara, gelir ve kurumlar vergisinden muaf olan dar mükelleflere dağıtılan, GVK'nın 75'inci maddesinin ikinci fıkrasının (1) ve (3) numaralı bendinde belirtilen kâr paylarından 2009/14592 sayılı Bakanlar Kurulu Kararı ile 03/02/2009 tarihinden itibaren geçerli olmak üzere \%15 oranında gelir vergisi tevkifatı yapılacağı hükmü yer almaktadır. Bu hüküm uyarınca, anonim şirketler tarafından hisse senedi sahipleri ile yönetim kurulu başkan ve üyelerine verilen kâr payları üzerinden \%15 oranında gelir vergisi tevkifatı yapılacaktır. Kâr payları üzerinden yapılan vergi tevkifatı, kar payına kaynak teşkil eden kurum kazancının istisna olup olmadığına bakılmaksızın karın dağıtılması aşamasına bırakılmıştır (Maliye Bakanlığı Gelirler Genel Müdürlüğü, 11/02/2004 tarih ve 15 sayılı Gelir Vergisi Sirküleri). Menkul sermaye iratlarının vergilendirilmesinde temel uygulama tevkifat müessesesidir (Özyılmaz, 2012: 156).

Anonim şirket yönetim kurulu üyesinin yönetim kurulu üyesi sıfatıyla aldığı kâr payları ile bu yönetim kurulu üyesinin aynı zamanda anonim şirket hisse senedi sahibi yani şirket ortağı olması nedeniyle hisse sahibi sıfatıyla aldığı kâr payları üzerinden kâr payı dağııımını yapan şirket bünyesinde tevkifat suretiyle vergilendirme söz konusudur.

\section{Sonuç}

Yürürlükteki kanunlar uyarınca bir kişinin bir anonim şirkette hem yönetim kurulu üyesi, hem şirket ortağı, hem de şirket çalışanı olarak bulunması mümkündür. Her üç sıfatı şahsında toplayan bu kişiye bu sıfatlarının her birine göre anonim şirket tarafından ödeme yapılmasına engel bir yasal düzenleme bulunmamaktadır.

Anonim şirket yönetim kurulu başkan ve üyelerine bu görevleri nedeniyle, "huzur hakkı", "ücret", "ikramiye", "prim" ve "kâr payı" adı altında TTK ile sınırlı sayı ilkesine göre belirlenen mali hakların verilmesi mümkündür. Bu adlar altında yapılan ödemeler Gelir Vergisi Kanununa göre "ücret" olarak vergilendirilir. Illave olarak anonim şirket ile hizmet akdi kapsamında işçi-işveren ilişkisi uyarınca ilişki içinde olan kişilere yapılan ödemeler de her ne ad altında yapılırsa yapılsın vergi kanunları uyarınca ücret olarak vergilendirilirler. Anonim şirketin hem yönetim kurulu üyesi hem de genel müdür ya da genel müdür yardımcısı gibi bir sıfatla çalışanı, daha açık bir deyimle şirketin işçisi vasfını taşıyan kişinin bu sıfatları nedeniyle sağladığı gelirler "ücret" geliri olarak vergilendirilir.

Anonim şirket yönetim kurulu başkan ve üyelerine bu görevleri nedeniyle, kâr payı olarak yapılan ödemeler de "menkul sermaye iradı" olarak vergiye tabi kılınmıştır. Benzer şekilde anonim şirketlerin ortaklarına yani hisse sahiplerine yapılan kâr payı ödemeleri de "menkul sermaye iradı" olarak vergilendirilmektedir. Buna göre anonim şirket yönetim kurulu üyesi ve aynı zamanda da ortağı olan bir kişinin gerek yönetim kurulu üyesi sıfatıyla gerekse de şirket ortağı sıfatıyla aldığı kâr payları menkul sermaye iradı kapsamında vergilendirmeye konu teşkil ederler. Yönetim kurulu başkan ve üyelerine verilen kâr paylarının ücret olarak değil de menkul sermaye iradı olarak vergilendirilmesi kanun koyucunun bilinçli bir tercihidir. Nitekim yönetim kurulu üyeleri dışında kalan şirket çalışanlarına yapılan kâr payı ödemeleri menkul sermaye iradı olarak değil ücret olarak vergilendirilmektedir (Seviğ, 2010: 7).

Çalışmamıza konu teşkil eden aynı anda hem şirket yönetim kurulu üyesi hem şirket ortağı hem de şirket çalışanı olan kişiye bu üç sıfatı nedeniyle yapılan tüm ödemeler vergi kanunları karşısında "ücret" ya da "menkul sermaye" iradı mahiyetindedir. Bu kişiye söz konusu sıfatları nedeniyle anonim şirket tarafından bu iki gelir unsuru dışında bir ödeme yapılması söz konusu değildir. Aynı anda; anonim şirket yönetim kurulu 
üyesi, ortağı ve çalışanı olan bir kişiye yapılan bir ödemenin ücret ya da menkul sermaye iradı olarak vergilendirilmesi hem ödemeyi yapan anonim şirketler hem de bu ödemelerinin yapıldığı kişiler açısından usul, esas ve neticeleri itibarıyla farklılıklar arz etmektedir.

\section{Kaynaklar}

Akbulak, Y. (2002). Halka açık anonim şirketlerde kâr payı ve temettü avansı dağııımı esasları. Vergi Dünyası, 249, 120131.

Akdağ Güney, N. (2010). Anonim şirket yönetim kurulu üyelerinin hukuki sorumluluğu (2.Baskı). İstanbul: Vedat Kitapçlık.

Akdağ Güney, N. (2012). 6102 sayılı ticaret kanuna göre anonim şirket yönetim kurulu üyelerinin hukuki sorumluluğu, İstanbul: Vedat Kitapçוlık.

Altaş; Soner (2017). Türk ticaret kanunu'na göre anonim şirketler, (8.Baskı). Ankara: Seçkin Yayıncılık.

Altındağ, M. (2002). 2001 yılında elde edilen menkul sermaye iratlarının beyanı. Yaklaşım, 110, 72-78.

Ansay, T. (1982). Anonim şirketler hukuku (6. Baskı). Ankara: Banka ve Ticaret Hukuku Araştırma Enstitüsü Yayını.

Ateşağaoğlu, E. (2012). Vergi hukuku bakımından anonim şirketlerde kâr payı dağııımı. İstanbul: On iki Levha Yayıncılık.

Bahtiyar, M. (2015). Ortaklıklar hukuku (9. Bası). İstanbul: Beta Yayınevi.

Bilgili, F., \& Demirkapı, E. (2013). Şirketler hukuku. Bursa: Dora Yayıncııı.

Bilici, N. (2014). Vergi hukuku cilt:1 (33. Baskı). Ankara: Savaş Yayınevi.

Bulutoğlu, K. (2004). Türk vergi sistemi. İstanbul: Batı Türkeli Yayınclık.)

Çamoğlu, E. (2010). Anonim ortaklık yönetim kurulu üyelerinin hukuki sorumluğu (3.Baskı. İstanbul: Vedat Kitapçıllı.

Çelik, A. (2017). Ticaret hukuku (7.Baskı). Ankara: Seçkin Yayınclık.

Çelik, N. (2004). İs hukuku dersleri (17.Baskı). isstanbul: Beta Yayınevi.

Çelik, N., Caniklioğlu, N., \& Canbolat, T. (2014). İş hukuku dersleri (27. Bası). İstanbul: Beta Yayınevi.

Çenberci, M. (1986). İs kanunu şerhi. Ankara: Seçkin Yayıncılık.

Çolak, M. (2004). Stopaj ve sorumluluk müessesesi. Ankara: Yaklaşım Yayıncılık.

Develi, E. (2016). Tüzel kişinin anonim şirket yönetim kurulu üyeliği. Ankara: Seçkin Yayıncılık.

Diliçıkık, A. (2015). Anayasa mahkemesi kararı sonrasında ödenmeyen amme alacaklarından kanuni temsilcilerin sorumluluğu. Vergi Dünyası, 34(407), 36-45

Ekici, i. (2011). Türkiye'de sadece menkul sermaye iradı elde eden dar mükellef gerçek kişilerde vergilendirme esasları. Maliye ve Sigorta Yorumları, 22(552), 116-126.

Erginay, A. (1987). Kamu maliyesi (12. Baskı). Ankara: Turhan Kitabevi.

Erimez, R. (1985). Şirketlerde kâr dağıtımı yedek akçeler ve vergilendirme (3. Baskı). İstanbul: Temel Yayınları.

Eriş, G. (2013). Ticari işletme ve şirketler cilt:Il (2. Baskı). Ankara: Seçkin Yayıncılık.

Evcil, C., \& Göktaş, K. (2010). Tüm yönleriyle ücretlendirme ve bordrolama esasları. İstanbul: Legal Yayıncılık.

Gümüş, M. A. (2013). Borçlar hukuku özel hükümler cilt I. İstanbul: Vedat Kitapçlık.

Günay, C. I. (2006). Ücret ödemede gecikmenin hukuki sonuçları. Sicil iş Hukuku Dergisi, istanbul: 1, 36-52.

https://www.tbmm.gov.tr/sirasayi/donem23/yil01/ss96.pdf (Erişim tarihi, 10 Şubat 2018).

Karaca, B. (2010). Anonim ortaklıkta müdürler ve hukuki sorumlulukları (2. Baskı). İstanbul: Vedat Kitapçıık.

Karahan, S. (Edit) (2013). Şirketler hukuku (2. Baskı). Konya: Mimoza Yayınları.

Karayalçın, Y. (1990). Kanuni yedek akçenin ilk ayrımı açısından safı kâr kavramı ve dönem vergi borçları. BATiDER, 15(3), 137-147.

Kayar, i. (2017). 6102 sayılı Türk ticaret kanunu'na göre ticaret hukuku (Güncellenmiş 4.Baskı). Ankara: Seçkin Yayıncılık.

Keser, H. (2010). Temerrüt durumunda ücret ve ikramiye alacaklarına uygulanacak faiz oranı ve faizin başlangııına ilişkin yargıtay kararının değerlendirilmesi. Sicil iş̧ Hukuku Dergisi, i̇stanbul: 17, 229-242.

Kırca, i., Şehirali Çelik, F. H., \& Manavgat, Ç. (2013). Anonim şirketler hukuku, cilt:1. Ankara: Banka ve Ticaret Hukuku Araştırma Enstitüsü Yayını.

Kızılot, Ş., \& Taş, M. (2011). Vergi hukuku ve türk vergi sistemi. Ankara: Yaklaşım Yayıncılık. 
Korkut, Ö.,(2007). Anonim şirketlerde inançlı yönetim kurulu üyeliği. Ankara: Adalet Yayınevi.

Mollamahmutoğlu, H., Astarlı, M., \& Baysal, U., (2014). İş hukuku (6.Baskı). Ankara: Turhan Kitapevi.

Mutluer, M. K., \& Dayanç, N. N., (2014). Vergi hukuku genel ve özel hükümler. Ankara: Turhan Kitapevi.

Odman Boztosun, A. (2013). Hukuksal açıdan bağımsız yönetim kurulu üyeliği. Ankara: Seçkin Yayıncılık.

Öncel, M., Kumrulu, A., \& Çağan, N. (2014). Vergi hukuku (23.Baskı). Ankara: Turhan Kitapevi.

Öner, E. (2013). Vergi hukuku ve Türk vergi sistemi (2. Baskı). Ankara: Seçkin Yayıncılık.

Öz, S. (2006). Gelir vergisinde vergiyi doğuran olay elde etme. Ankara: Maliye ve Hukuk Yayınları.

Özer, I. (2013). Türk ve yabancı hukuk sistemlerinde anonim şirket yöneticilerinin mali hakları. Ankara: Adalet Yayınevi.

Öztürk, İ. (2012). Türk sermaye piyasasında vergi harcamaları. İstanbul: İstanbul Altın Borsası Yayın No:23.

Öztürk, i. (2016a). Anonim şirket tüzel kişi yönetim kurulu üyelerinin mali hakları arasında yer alan ücret niteliğindeki ödemelerin vergilendirilmesine ilişkin belirsizlikler. Legal Hukuk Dergisi, 14(160), 2023-2050.

Öztürk, ì. (2016b). 6102 sayılı Türk ticaret kanunu'nun yürürlüğe girmesiyle anonim şirket yönetim kurulu üyeliğine seçilmeleri mümkün olan tüzel kişilere yönetim kurulu üyesi sıfatıyla ödenen kâr paylarının vergilendirilmesi. Başkent Üniversitesi Hukuk Fakültesi Dergisi, 2(1), 93-120

Öztürk, ì. (2016c). Vergi hukuku kapsamında anonim şirketlerin tüzel kişi yönetim kurulu üyelerinin kanuni temsilci sıfatıyla sorumluluğu. Türkiye Adalet Akademisi Dergisi, 7(24), 309-334.

Öztürk, i. (2016d). Vergi planlaması bağlamında anonim şirketlerin yönetim kurulu başkan ve üyelerine yapılan ödemelerin hukuki niteliği ve vergilendirilmesi. Mali Hukuk Dergisi, 12(133), 55-84.

Öztürk, ì. (2016e). Bütçe kanununa ekli vergi harcamaları listesinin mevzuatla ücret gelirlerine ilişkin getirilen muafiyet, istisna ve indirimler bağlamında analizi. Sosyoekonomi, 24(27), 57-84.

Öztürk, ì. (2016f). Vergi benzeri mali yükümlülükler. Ankara: Yetkin Yayınları.

Öztürk, i. (2016g). Kanuni temsilci sıfatıyla anonim şirket yönetim kurulu üyelerinin gümrük vergilerinden sorumluluğu. Vergi Dünyası, 416. 239-252.

Paslı, A. (2005). Anonim ortaklık kurumsal yönetimi (2.Baskı). İstanbul: Çağa Vakfı Yayınları.

Poroy, R., Tekinalp, Ü., \& Çamoğlu, E., (2003). Ortaklıklar ve kooperatifler hukuku (9.Baskı). İstanbul: Beta Yayınları.

Pulaşlı, H. (2014). Şirketler hukuku şerhi cilt:1 (2. Baskı). Ankara: Adalet Yayınevi.

Sengir, T. (1973). Anonim ortaklıklarda kâr payı hakkı, BATiDER, 7(1), 77-86.

Sevi, A. M. (2004). Anonim ortaklıkta payın devri. Ankara: Seçkin Yayıncılık.

Seviğ, V. (2010, 18 Ağustos). Personele ödenen kâr payı, vergi kesintisine tabidir, Referans Gazetesi. http://www.mevzuatbankasi.com/portal/konuk_yazarlar/mevzuat.asp?kategori=138\&id=4902 (Erişim tarihi, 23 Ocak 2018).

Sümer, H. H. (2017). İş hukuku (22.Baskı). Ankara: Seçkin Yayıncılık.

Süzek, S. (2017). İş hukuku (14.Baskı). İstanbul: Beta Yayınevi.

Şener, A., \& Öztürk, í. (2012). Anonim şirketlerde pay sahibi olmayan denetim kurulu üyelerine ve denetçilere kar payı ödenmesinin hukuki ve mali analizi. İnönü Üniversitesi Hukuk Fakültesi Dergisi, 3(1), 151-186

Şener, O. H. (2015). Teori ve uygulamalı, ortaklıklar hukuku ders kitabı (2.Baskı). Ankara: Seçkin Yayıncılık.

Tekinalp, Ü. (2009). Ünal tekinalp'in banka hukukun esasları (3.Baskı). İstanbul: Vedat Kitapçılık.

Tekinalp, Ü. (2015). Sermaye ortaklıklarının yeni hukuku. İstanbul: Vedat Kitapçılık.

Tuncer, S. (2003). Kar paylarının vergilendirilmesinde “vergi alacağı”ndan “yarım beyan yöntemine. Vergi Dünyası, 265, 4-9.

Türkmen, C. (2015). 2014 yılında elde edilen menkul sermaye iratlarının vergilendirilmesi ve beyanı. Vergi Dünyası, 403, 132-141.

Uygur, T. (2012). 6098 sayılı türk borçlar kanunu şerhi cilt:ı (2.Baskı). Ankara: Seçkin Yayıncılık.

Uysal, A., \& Eroğlu, N. (2009). Açıklamalı ve örnekli vergi usul kanunu (4.Baskı). Ankara: Sözkesen Matbaacılık.

Ünal, A.C. (2001). Anonim şirketlerde kâr payı, kâr dağıtımı ve yedek akçe ayrılması. Başkent Üniversitesi, Basılmamış Yüksek Lisans Tezi, Ankara.

Ünal, O.K. (1998). Sermaye piyasası mevzuatında birinci temettü ve sermaye piyasası değişiklik tasarısı'nda bu konuda öngörülen değişiklikler. Yaklaşım, 64, 42-56. 
Yavuz, C. (2004). Borçlar hukuku dersleri özel hükümler (6.Baskı). İstanbul: Beta Yayınları.

Yıldız, Ş. (2004). Anonim ortaklıkta pay sahipleri açısından eşit işlem ilkesi. Ankara: Seçkin Yayıncılık.

Yüce, M. (2014). Anonim şirketlerde yönetim kurulu üyeleri kanuni temsilciler müdürler ile ortaklarının hak ve sorumlulukları. Bursa: Ekin Yayınları. 